\title{
Market Quality of Grapefruit after Heat Quarantine Treatments
}

\author{
Raymond G. McGuire \\ U. S. Department of Agriculture-Agricultural Research Service, \\ Subtropical Horticulture Research Station, 13601 Old Cutler Road, \\ Miami, FL 33158
}

\section{Additional index words Citrus paradisi, Caribbean fruit fly, Anastrepha suspensa, storage, juice}

\begin{abstract}
The market quality and condition of grapefruit (Citrus paradisi Macf.) were compared after three heat treatments for quarantine control of Caribbean fruit flies [Anastrepha suspensa (Loew)]. Treatment by forced air at $48 \mathrm{C}$ for 3 hours was compared with immersions in water at either a constant $48 \mathrm{C}$ for 2 hours or with a gradual increase to $48 \mathrm{C}$ lasting 3 hours. The immersion at a constant $48 \mathrm{C}$ significantly increased weight loss and promoted injury and decay while reducing firmness and color intensity after 4 weeks of storage. By more slowly heating fruit in the gradient water immersion, weight, firmness, and natural color were retained, and injury was substantially reduced, but the incidence of decay remained high. No loss in quality resulted from treatment by forced hot air. These heat treatments had little effect on juice characteristics, although acidity was slightly reduced by each method of application. In taste tests, juice from fruit treated in water that was gradually raised to $48 \mathrm{C}$ was preferred over that of fruit treated at a constant $48 \mathrm{C}$.
\end{abstract}

Grapefruit, when not harvested from flyfree zones in Florida, must undergo a quarantine treatment to eradicate the Caribbean fruit fly before export to California, Hawaii, and Japan. Treatment with ethylene dibromide, although effectively used against fruit fly infestations (Grierson and Hayward, 1959), is no longer registered for use in the United States, Japan, and other countries. Currently, cold storage and methyl bromide fumigation are federally approved practices for eradication of $\boldsymbol{A}$. suspensa (U.S. Dept. of Agriculture, 1985). Although cold treatment, which requires 3 weeks and is usually performed aboard ship in transit, is satisfactory for export of fruit to Japan, shippers would prefer speedier and more economical treatment for fruit that is sent to the large California market. Fumigation with methyl bromide, however, has been under review since the chemical was found to be carcinogenic in rats (Danse et al., 1984).

Heat treatment provides a quick alternative for insect disinfestation in various fruits and also offers some measure of disease control (Couey, 1989). Forty-three minutes at 43.3C is required to kill eggs of A. suspensa, the stage most resistant to heat (Sharp and Chew, 1987). However, as the center of fruit reaches $43.3 \mathrm{C}$, the outer tissue can become several degrees warmer. Grapefruit are sensitive to the high temperatures required for efficient insect eradication, especially when

Received for publication 15 Mar. 1991. I appreciate the assistance of Jerry Gaffney and Victor Chew. Mention of a trade name does not constitute a recommendation by the U.S. Dept. of Agriculture. The cost of publishing this paper was defrayed in part by the payment of page charges Under postal regulations, this paper therefore must be hereby marked advertisement solely to indicate this fact. heat is applied rapidly by immersing fruit into constant temperature baths (Miller et al., 1988; Sharp, 1985; Smoot and Melvin, 1965; Spalding and Reeder, 1985). Fruit scald often develops. Vapor heat, approved for disinfesting grapefruit of the Mexican fruit fly, Anastrepha ludens Loew (U.S. Dept. of Agriculture, 1985), is less damaging to fruit than hot water immersion and is also being developed for eradication of $A$. suspensa (Gaffney et al., 1990; Hallman et al., 1990; the use of forced hot air. Like vapor heat, treatment with hot air raises the temperature of the fruit slowly, but the dewpoint temperature is maintained below the level at which surface condensation would form (Gaffney and Armstrong, 1990; Sharp et al., 1991). With this treatment, scald injury can be avoided at moderately high temperatures (Sharp, 1989b).

In this report, damage to grapefruit associated with hot air treatment is compared with damage resulting from two methods of treatment in hot water. Constant-temperature hot water immersion is contrasted with a technique in which the water of a bath is gradually raised to treatment temperature. This latter method of heat transfer simulates the incremental increase of temperature within the hot air chamber.

Middle- and late-season 'Marsh' white grapefruit of size 36 were obtained in Jan., Mar., and Apr., 1990, from a packinghouse in central Florida. Except for grading, fruit were unprocessed and were secured within $24 \mathrm{~h}$ of harvest. The three tests, representing random lots of fruit, were considered to be experimental replications. Fruit were initially washed, then separated into four treatments that included forced air at $48 \mathrm{C}$, water immersion at a constant $48 \mathrm{C}$, water immersion with a gradual temperature increase to Miller et al., 1991). Another alternative is
48C, and control fruit that remained at ambient air temperature. Each treatment contained 108 fruit with an average weight of $466 \pm 95 \mathrm{~g} /$ fruit. All treatments were completed within 3 days, during which time the fruit were stored at $13 \mathrm{C}$ [95\% relative humidity (RH)] until their removal to $24 \mathrm{C} 24$ $\mathrm{h}$ before treatment. The fruit were individually weighed immediately before treatment.

For treatment with forced hot air, 36 fruit were placed into each of three plastic bins $(60 \times 40 \times 31 \mathrm{~cm})$ with bottoms of steel grating. The bins were stacked within the hot air chamber, and air at $48 \mathrm{C}$ (from 58\% to $90 \% \mathrm{RH})$ was forced through the column of fruit at an average $0.4 \mathrm{~m}^{3} \cdot \mathrm{s}^{-1}$ for $3 \mathrm{~h}$. The heating of the chamber was controlled by a computer program using as input the temperatures in the outer $1 \mathrm{~mm}$ of three fruit at the base of the column; these temperatures were monitored every $60 \mathrm{sec}$ using Type T copper-constantan thermocouples (Sharp et al., 1991). Data from another group of thermocouples, which monitored the chamber temperature, were collected into a computer file that was subsequently used in setting the temperatures of a group of six lo-liter water baths. These six baths were used for the immersion of fruit in water that was gradually heated to $48 \mathrm{C}$. Core temperatures of 10 fruit per treatment were monitored as described by Sharp (1989b). All heat treatments were continued for 43 min after the mean core temperature of the fruit reached 43.3C. Fruit in the hot air and the gradient hot water immersion reached $43.3 \mathrm{C}$ after $132 \pm 4 \mathrm{~min}$ for a total treatment time of $\approx 3 \mathrm{~h}$. A hot water immersion appliance (Sharp, 1989a) was used for the treatment of fruit in water at a constant $48 \mathrm{C}$; treatment required $2 \mathrm{~h}$. Control fruit remained at an air temperature of $24 \mathrm{C}$. After the treatments were completed, fruit were waxed (Fresh Wax 3202, Fresh Mark Corp.; Ocoee, Fla.) in a packing line facility. All fruit were stored at $13 \mathrm{C}$.

After 28 days of cold storage, fruit were evaluated for weight loss and visually rated for the incidence of decay and the incidence and severity of injury as described by Spalding and Reeder (1985). Firmness of each fruit was measured at two equatorial sites with an Instron model 1011 (Instron Corp., Canton, Mass.) fitted with a compression anvil of

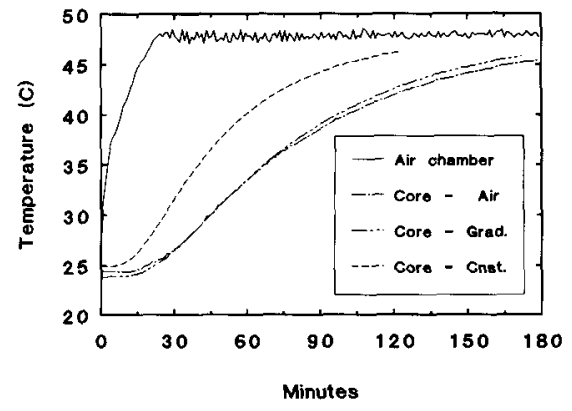

Fig. 1. Temperature changes within grapefruit during immersion in water at a constant 48C (Const.), immersion in water gradually raised to $48 \mathrm{C}$ (Grad.), and by treatment with forced air to $48 \mathrm{C}$. 


\begin{tabular}{|c|c|c|c|c|c|c|c|c|c|c|c|}
\hline \multirow[b]{3}{*}{ Treatment $^{\mathbf{x}, y}$} & \multirow{3}{*}{$\begin{array}{l}\text { Weight } \\
\text { loss } \\
(\%)\end{array}$} & \multirow{3}{*}{$\begin{array}{c}\text { Decay } \\
\text { incidence } \\
(\%)\end{array}$} & \multirow{2}{*}{\multicolumn{2}{|c|}{ Injuryx (\%) }} & \multirow{2}{*}{\multicolumn{2}{|c|}{ Colorw }} & \multirow[b]{3}{*}{ Firmness" } & \multicolumn{3}{|c|}{ Juice } & \multirow[b]{3}{*}{ Taste $^{\mathrm{u}}$} \\
\hline & & & & & & & & & Acids & Solids & \\
\hline & & & Incidence & Severity & Hue & Intensity & & $\mathrm{pH}$ & $(\%)$ & $(\%)$ & \\
\hline $\begin{array}{l}\text { Control } \\
\text { Air } 48 \mathrm{C} \text { gradient } \\
\text { Water } 48 \mathrm{C} \text { gradient } \\
\text { Water } 48 \mathrm{C} \text { constant }\end{array}$ & $\begin{array}{l}2.7 \mathrm{a} \\
3.3 \mathrm{~b} \\
2.5 \mathrm{a} \\
3.5 \mathrm{~b}\end{array}$ & $\begin{array}{r}1.2 \mathrm{a} \\
2.5 \mathrm{a} \\
46.0 \mathrm{~b} \\
65.7 \mathrm{~b}\end{array}$ & $\begin{array}{r}7.4 \mathrm{a} \\
17.6 \mathrm{a} \\
43.2 \mathrm{~b} \\
84.3 \mathrm{c}\end{array}$ & $\begin{array}{r}0.6 \mathrm{a} \\
1.4 \mathrm{a} \\
7.6 \mathrm{a} \\
48.8 \mathrm{~b}\end{array}$ & $\begin{array}{l}91.68 \mathrm{a} \\
90.13 \mathrm{~b} \\
90.43 \mathrm{~b} \\
85.99 \mathrm{c}\end{array}$ & $\begin{array}{l}54.77 \mathrm{ab} \\
56.02 \mathrm{a} \\
54.15 \mathrm{~b} \\
47.11 \mathrm{c}\end{array}$ & $\begin{array}{l}26.76 \mathrm{a} \\
27.12 \mathrm{a} \\
26.77 \mathrm{a} \\
21.42 \mathrm{~b}\end{array}$ & $\begin{array}{l}3.44 \mathrm{a} \\
3.60 \mathrm{c} \\
3.55 \mathrm{~b} \\
3.53 \mathrm{~b}\end{array}$ & $\begin{array}{l}1.06 \mathrm{a} \\
0.90 \mathrm{~b} \\
0.92 \mathrm{~b} \\
0.94 \mathrm{~b}\end{array}$ & $\begin{array}{l}12.2 \mathrm{a} \\
12.1 \mathrm{a} \\
12.3 \mathrm{a} \\
12.3 \mathrm{a}\end{array}$ & $\begin{array}{r}0.118 a \\
-0.130 b \\
0.152 a \\
-0.140 b\end{array}$ \\
\hline
\end{tabular}

Treatment times: Constant temperature water immersion for $120 \mathrm{~min}$, air and gradient water immersion for $180 \mathrm{~min}$.

within columns, numbers followed by the same letter are not significantly different $(P=0.05$, Ryan-Einot-Gabriel-Welsch multiple $\mathrm{F}$ test). Means of three harvests $(3 \times 108$ fruit Per treatment $)$.

${ }^{\mathrm{x}}$ Severity as Percent surface area pitted or scalded, mean separation from an analysis of injury ratings.

${ }^{\mathrm{w}}$ Values derived from measurement using a Minolta CR-200 chromameter. Hue angle: $0^{\circ}=$ red, $90^{\circ}=$ yellow, $180^{\circ}=$ green.

'Instron measurement in Newtons; resistance to pressure of $5 \mathrm{~mm}$ by anvil of $5.75-\mathrm{cm}$ diameter.

"Samples were ranked in preference. The most preferred received a score of 1.03 , the second received 0.30 , the third received - 0.30 , and the least preferred received -1.03 .

diameter $5.75 \mathrm{~cm}$; resistance to pressure was recorded after a compression of $5 \mathrm{~mm}$ and averaged per fruit. Color was evaluated at four sites about the equator of each fruit with a Minolta CR-200 chroma meter (Minolta Corp., Ramsey, N.J.) recording in the Hunter "L a b" system (Francis, 1980). As recommended by Little (1975), hue angle (arctangent $b / a)$ and saturation index $\left[\left(a^{2}+b^{2}\right)^{1 / 2}\right]$ were calculated, then average values were determined for individual fruit for subsequent statistical analyses. Thirty fruit from each treatment were also individually juiced; $\mathrm{pH}$, titratable acidity expressed as anhydrous citric acid, and total soluble solids were measured as described by Hatton and Reeder (1968). Three informal taste tests were conducted to compare juice from each treatment, with 16 to 19 people rating the four samples from most to least preferred. Each taste test was replicated once using juice from another composite of four different fruit per treatment.

The data were tested with an analysis of variance and by means separation (Ryan-Einot-Gabriel-Welsch multiple $F$ test) in SAS (SAS Institute, Inc., 1985). Rating values for the severity of injury were analyzed directly, then ratings were converted to proportions for a determination of mean percent surface area injured. Before analysis of the color data, hue angle was converted from a scale of $-90^{\prime \prime}$ to $90^{\circ}$ into one of $0^{\circ}$ to $180^{\circ}$ that is more appropriate for grapefruit. All other data were analyzed directly. Taste tests were statistically evaluated according to Fisher and Yates (1949), using scores for ranked data.

At a setting of $48 \mathrm{C}$, air within the hot air chamber averaged $47.9 \pm 0.3 \mathrm{C}$ after the initial 30-min rise in temperature (Fig. 1). Water temperatures in the gradient water baths followed a profile identical to that within the hot air chamber, and the rate of temperature increase within the fruit was the same for both techniques. This rate was slower than that in fruit treated in water at a constant $48 \mathrm{C}$ $(48.0 \pm 0.2 \mathrm{C})$. When treatments were completed, the mean temperature of the pulp within the fruit core was $45.6 \mathrm{C}$ with forced air and gradient water immersion and 46.3C after the constant temperature immersion. Peel temperatures approximated the temperatures of each heating regime.
At the end of 4 weeks of storage, weight loss was significantly affected by the method of heat application (Table 1). Water immersion at a constant $48 \mathrm{C}$ and hot air treatment produced the most weight loss. Weight loss from fruit treated by immersion in water that was gradually increased to $48 \mathrm{C}$ was not significantly different from that of control fruit.

Decay, primarily from Penicillium digitatum Sacc., was also significantly affected by the type of heat treatment (Table 1). Unlike treatment with hot air, where the incidence of decay did not differ significantly from that in control fruit, treatment by immersion in hot water produced extensive decay. Gradual and constant heating in water gave similar results, with disease incidence in two of the three tests averaging $>50 \%$.

Rind injury, primarily pitting and scalding, was most severe in grapefruit treated by immersion at a constant 48C (Table 1). Gradually heating the water, however, significantly reduced the incidence and severity of injury. Although injury from gradual heating in water averaged $<10 \%$ of the surface area, nearly half the fruit were damaged to some extent. The degree of injury resulting from hot air treatment was not significantly different from that in control fruit.

When compared with control fruit, all heat treatments accelerated the loss of green pigmentation during storage, but neither treatment with forced air nor with gradient water immersion affected color intensity or the firmness of the fruit (Table 1). In contrast, a constant immersion at $48 \mathrm{C}$ significantly softened fruit, altered color by producing pink undertones indicative of scald, and reduced color intensity.

Heat treatment raised the $\mathrm{pH}$ of grapefruit juice and lowered the percentage of citric acid, but it did not significantly affect the percentage of total soluble solids (Table 1). Overall, juice from control fruit and from fruit gradually heated in water to $48 \mathrm{C}$ was preferred in taste tests over juice from fruit treated with hot air or by immersion at a constant $48 \mathrm{C}$. In two of three individual tests, however, preferences were not significantly different (data not shown).

Damage to grapefruit may be especially severe when heat is applied by immersion in water at a constant $46 \mathrm{C}$ or above (Miller et al., 1988; Sharp, 1985; Smoot and Melvin,
1965; Spalding and Reeder, 1985). It is the sudden impact of this heat on the fruit surface, however, that is most damaging; when gradually applied, treatment temperatures to $48 \mathrm{C}$ can be successfully used. Treatment with hot air is promising for grapefruit (Sharp, 1989b), but immersion in water may be equally practical if temperatures are gradually raised. A disadvantage of hot water immersion for grapefruit appears to be the greater inducement to storage decay. Perhaps this enhanced susceptibility could be minimized by warming the fruit before treatment to $>24 \mathrm{C}$ or by adding a fungicide, such as imazalil, to the wax applied afterward (Kaplan and Dave, 1979).

\section{Literature Cited}

Couey, H.M. 1989. Heat treatment for control of postharvest diseases and insect pests of fruits. HortScience 24:198-202.

Danse, L.H.J.C., F.L. van Velson, and C.A. van der Heuden. 1984. Methylbromide: carcinogenic effects in the rat forestomach. Toxicol. Applied Pharmacol. 72:262-271.

Fisher, R.A. and F. Yates. 1949. Statistical tables for biological, agricultural, and medical research. Oliver and Boyd, London.

Francis, F.J. 1980. Color quality evaluation of horticultural crops. HortScience 15:58-59.

Gaffney, J.J. and J.W. Armstrong. 1990. Hightemperature forced-air research facility for heating fruits for insect quarantine treatments. J. Econ. Entomol. 83:1959-1964.

Gaffney, J.J., G.J. Hallman, and J.L. Sharp 1990. Vapor heat research unit for insect quarantine treatments. J. Econ. Entomol. 83:1965-1971.

Grierson, W. and F.W. Hayward. 1959. Fumigation of Florida citrus fruit with ethylene dibromide. Proc. Amer. Soc. Hort. Sci. 73:267277.

Hallman, G.J., J.J. Gaffney, and J.L. Sharp. 1990. Vapor heat treatment for grapefruit infested with Caribbean fruit fly (Diptera: Tephritidae). J. Econ. Entomol. 83:1475-1478.

Hatton, T.T. and W.F. Reeder. 1968. Quality of persian limes after different packinghouse treatments and storage in various controlled atmospheres. Proc. Amer. Soc. Hort. Sci. 11:2332.

Kaplan, H.J. and B.A. Dave. 1979. The current status of imazalil: a Post harvest fungicide for citrus. Proc. Fla. State Hort. soc. 92:37-43.

Little, A.C. 1975. Off on a tangent. J. Food Sci. 40:410-411.

Miller, W.R., R.E. McDonald, G. Hallman, and 
J.L. Sharp. 1991. Condition of Florida grapefruit after exposure to vapor heat quarantine treatment. HortScience 26:424.

Miller, W.R., R.E. McDonald, T.T. Hatton, and M. Ismail. 1988. Phytotoxicity to grapefruit exposed to hot water immersion treatment. Proc. Fla. State Hort. Sci. 101:192-195.

SAS Institute Inc. 1985. SAS user's guide: statistics, version 5 (ed.). SAS Institute Inc., Gary, N.C.

Sharp, J.L. 1985. Submersion of Florida grapefruit in heated water to kill stages of Caribbean fruit fly. Anastrepha suspensa. Proc. Fla. State
Hort. Soc. 98:78-80.

Sharp, J.L. 1989a. Hot-water immersion appliance for quarantine research. J. Econ. Entomol. 82:189-192.

Sharp, J.L. 1989b. Preliminary investigation using hot air to disinfest grapefruit of Caribbean fruit fly immatures. Proc. FIa. State Hort. Soc. 102:157-159.

Sharp, J.L. and V. Chew. 1987. Time/mortality relationships for Anastrepha suspensa (Diptera: Tephritidae) eggs and larvae submerged in hot water. J. Econ. Entomol. 80:646-649.

Sharp, J.L., J.J. Gaffney, J.I. Moss, and W.P.
Gould. 1991. Hot-air treatment device for quarantine research. J. Econ. Entomol. 84:52-527.

Smoot, J.J. and C.F. Melvin. 1965. Reduction of citrus decay by hot-water treatment. Plant Dis. Rpt. 49:463-476.

Spalding, D.H. and W.F. Reeder. 1985. Effect of hot water and gamma radiation on postharvest decay of grapefruit. Proc. FIa. State Hort. Soc. 98:207-208.

U.S. Department of Agriculture, Animal and Plant Health Protection Services. 1985. Plant protection and quarantine treatment manual. Sec. VI: T102, T106, and T107, Washington, D.C. 